\title{
FIELD PERFORMANCE OF 'MARSH SEEDLESS' GRAPEFRUIT ON TRIFOLIATE ORANGE INOCULATED WITH VIROIDS IN BRAZIL
}

\author{
Eduardo Sanches Stuchi ${ }^{1,2 *}$; Simone Rodrigues da Silva²; Luiz Carlos Donadio²; Otávio \\ Ricardo Sempionato ${ }^{2}$; Eduardo Toller Reiff ${ }^{2}$ \\ ${ }^{1}$ Embrapa Mandioca e Fruticultura Tropical, R. Embrapa s/n ,C.P. 7 - 44380-000 - Cruz das Almas, BA - Brasil. \\ ${ }^{2}$ Estação Experimental de Citricultura de Bebedouro, C.P. 74 - 14700-971 - Bebedouro, SP - Brasil. \\ *Corresponding author <stuchi@estacaoexperimental.com.br>
}

\begin{abstract}
Some viroids reduce citrus tree growth and may be used for tree size control aiming the establishment of orchards with close tree spacing that may provide higher productivity than conventional ones. To study the effects of citrus viroids inoculation on vegetative growth, yield and fruit quality of 'Marsh Seedless' grapefruit (Citrus paradisi Macf.) grafted on trifoliate orange [Poncirus trifoliata (L.) Raf.], an experiment was set up in January 1991, in Bebedouro, São Paulo State, Brazil. The experimental design was randomized blocks with four treatments with two plants per plot: viroid isolates Citrus Exocortis Viroid (CEVd) + Hop stunt viroid (HSVd - CVd-II, a non cachexia variant) + Citrus III viroid (CVd-III) and Hop stunt viroid (HSVd - CVd-II, a non cachexia variant) + Citrus III viroid (CVd-III) and controls: two healthy buds (control), and no grafting (absolute control). Inoculation was done in the field, six months after planting by bud grafting. Both isolates reduced tree growth (trunk diameter, plant height, canopy diameter and volume). Trees not inoculated yielded better (average of eleven harvests) than inoculated ones but the productivity was the same after 150 months. Fruit quality was affected by viroids inoculation but not in a restrictive way. The use of such severe dwarfing isolates for high density plantings of grapefruit on trifoliate orange rootstock is not recommended.
\end{abstract}

Key words: growth, yield, fruit quality, exocortis, dwarfing

\section{DESEMPENHO DO POMELEIRO ‘MARSH SEEDLESS’ ENXERTADO EM TRIFOLIATA INOCULADO COM VIRÓIDES NO BRASIL}

\begin{abstract}
RESUMO: Alguns viróides reduzem o crescimento dos citros e podem ser usados para o controle do tamanho das plantas objetivando a instalação de pomares adensados que podem ter maior produtividade que os pomares com espaçamentos convencionais. Para estudar o efeito da inoculação de viróides no desenvolvimento vegetativo, produção e qualidade dos frutos de pomeleiro 'Marsh Seedless' (Citrus paradisi Macf.) enxertado em trifoliata [Poncirus trifoliata (L.) Raf.], foi instalado um experimento em Janeiro de 1991, em Bebedouro, Estado de São Paulo, Brasil. O delineamento experimental foi em blocos casualizados com quatro tratamentos e duas plantas por parcela: viróides dos citros (CEVd + CVd-II + CVd-III) e (CVd-II + CVd-III) e testemunhas: enxertia de duas borbulhas sadias (testemunha) e sem enxertia (testemunha absoluta). A inoculação foi feita no campo, seis meses após o plantio, por enxertia de borbulhas. Ambos isolados reduziram o crescimento das árvores (diâmetro do tronco, altura da planta diâmetro e volume da copa). As árvores não inoculadas produziram mais que as inoculadas nas onze colheitas realizadas, mas as produtividades foram similares. A qualidade dos frutos foi afetada pela inoculação de viróides, mas não de maneira restritiva. O uso de isolados ananicantes severos não deve ser recomendado para plantios de alta densidade de pomelo enxertado em trifoliata.
\end{abstract}

Palavras-chave: crescimento, produção, qualidade de frutos, exocorte, nanismo

\section{INTRODUCTION}

High density citrus plantings provide higher productivity than conventional ones mainly in the early years but, as soon as they grow older, tree size be- comes a problem (Golomb, 1989; Tucker et al., 1991). Tree size control not only facilitates cultural practices and picking, but also allows the establishment of orchards with close spacing (Forsyth et al., 1993). The characteristics and grouping of citrus viroids which 
can reduce tree growth and yield without affecting crop efficiency and fruit quality have been summarized by Semancik \& Roistacher (1991a, 1991b). Viroids as dwarfing agents have been investigated in several countries (Polizzi et al., 1994; Vuuren \& Graça, 1997a, 1997b; Pérez et al., 1994; Semancik et al., 1997, 2002; Vogel et al., 1974; Cohen, 1968, 1974; Stuchi et al., 1998; Vernière et al., 2004, 2006) and commercially recommended in Australia and Israel (Forsyth et al., 1993; Broadbent et al., 1994; Ashkenazi \& Oren, 1989; Bar-Joseph, 1993). Viroids may be considered as transmissible, small, nuclear ribonucleic acids affecting plant growth (Semancik et al., 1997, 2002). However there are restrictions for some of their use such as susceptibility to frost injury, yield reduction, potential pathogenicity to other citrus varieties, the possible association of viroids with as yet unidentified diseases and the potential for distributing viroids which may affect other crops (Roistacher, 1994) and others citrus orchards due to mechanical transmission that could occur in the field by pruning and harvesting operations (Barbosa et al., 2005).

The objectives of this study were to evaluate the effects of citrus viroid inoculation on vegetative growth, yield and fruit quality of 'Marsh Seedless' grapefruit on trifoliate orange aiming the establishment of high density plantings.

\section{MATERIAL AND METHODS}

The experiment was carried out in Bebedouro

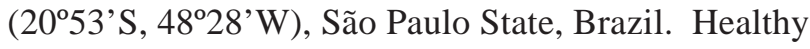
nursery trees of 'Marsh Seedless' grapefruit (Citrus paradisi Macf.) grafted on trifoliate orange [Poncirus trifoliata (L.) RAF.] were planted in January 1991, with spacing of $7 \mathrm{~m}$ between rows and $3 \mathrm{~m}$ between plants. The treatments were: i) absolute control with no grafting; ii) two healthy bud grafts; iii) inoculation with a viroid isolate carrying CVd-II and CVdIII, and iv) inoculation with a viroid isolate carrying CEVd, CVd-II and CVd-III. The isolates were previously reported as mild (treatment iii) and severe (treatment iv) strains of exocortis (Pompeu Junior et al, 1976). The experimental design was randomized blocks with five replications and two trees per plot.

The isolates were characterized by biological indexing and sPAGE (Stuchi et al., 1998) and the viroids had their complete genome sequenced (Targon et al., 2001) and registered in the GenBank under code numbers AF434678 (CEVd), AF434679 (HSVd, a non cachexia variant) and AF434680 (CVdIII). Inoculation was done in September, 1991, six months after planting, two buds per tree from trees carrying the isolates: one in the scion and the other one in the rootstock. After sprouting buds were blinded.

Trunk diameter was evaluated for the scion and the rootstock $5 \mathrm{~cm}$ above and below the bud union annually between 1991 and 1998 and in 2003 and 2004. Tree height and canopy diameter was evaluated annually between 1992 and 1999 and in 2003 and 2004. Canopy volume was calculated through the formula: $\mathrm{V}=2 / 3\left(\Pi \mathrm{R}^{2} \mathrm{H}\right)$, where $\mathrm{V}=$ canopy volume, $\mathrm{R}=$ radius and $\mathrm{H}=$ tree height (Pompeu Junior et al., 1976). Harvest weighing was done by plots between 1994 and 2004 and the yield per tree was calculated. Crop efficiency was obtained by dividing the yield (kg tree $\left.^{-1}\right)$ by the volume of trees $\left(\mathrm{m}^{3}\right)$ and the results were expressed in $\mathrm{kg}\left(\mathrm{m}^{3}\right)^{-1}$.

Fruit quality was evaluated during harvest time between 1996 and 2001 having 10 fruits per plot as samples. The following physical and chemical characteristics were determined: height and diameter, weight, juice content, total soluble solids (TSS), acidity, maturation index or ratio and technological index $(\mathrm{TI}=[\mathrm{TSS} \times$ juice content $\times 40.8] / 10000)$ that express the amount of TSS in a standard field box of $40.8 \mathrm{~kg}$. The theoretical optimal planting density and calculated theoretical potential yields were based on the assumption that no reduction in size or yield was due to close spacing (Pompeu Junior et al., 1976). The theoretical optimal spacing for the trees was calculated based on the assumption that adjacent trees should overlap 15\% in the row and that these should have 2.5 $\mathrm{m}$ of open space between the rows (De Negri \& Blasco, 1991). Results were submitted to analysis of variance and the averages compared by the Tukey test $(P<0.05)$.

\section{RESULTS AND DISCUSSION}

Confirmation of viroid infection in the experimental trees by biological indexing and sPAGE has already been reported (Stuchi et al., 1998). Viroid segregation occurred in two plots on which trees received the CEVd isolate; in one of them there was a lack of CEVd in one tree, for the other the two trees had not CVd-II and in both plots reduction in tree size and scaling occurred (Stuchi et al., 2001). Such viroid segregation have also been reported in Israel (Hadas et al., 1989) and Australia (Broadbent et al., 1994). Trunk symptoms on trifoliate orange were typical of exocortis (scaling) for the isolate with CEVd, 46 months after inoculation. The isolate without CEVd did not cause any scaling till the $150^{\text {th }}$ month after inoculation as reported by Verniere et al. (2006). 
At the time of inoculation trunk diameters were similar to all treatments, indicating an uniformity of the experimental trees (Tables 1, 2). Viroid effects on scion trunk diameter of scion were noticed 30 months after inoculation of both isolates. CEVd and non CEVd isolates differed from controls but not from each other for most of the dates. Reductions of nearly 39\% and $29 \%$ related to absolute control were observed at the $150^{\text {th }}$ month for both viroids isolates with and without CEVd, respectively (Table 1). Regarding rootstock, both isolates reduced trunk diameter 30 months after inoculation compared to the absolute control, but did not differ from each other. Differences between isolates were observed earlier (month 54) than for the scion diameter. Reductions of rootstock diameter comparing to absolute control were nearly $44 \%$ and $29 \%$ for the isolates with and without CEVd, respectively (Table 2).
Regarding canopy diameter, the effect of both viroids isolates was observed 54 months after inoculation. Differences between isolates started at the $90^{\text {th }}$ month. A reduction of nearly $44 \%$ and $25 \%$ relative to absolute control was observed after 150 months for the isolates with and without CEVd, respectively (Table $3)$. Tree height differences were observed 30 months after inoculation of both isolates which differed from the controls but not from each other. After 150 months, a reduction of nearly $47 \%$ and $29 \%$ compared to absolute control was observed for the isolates with and without CEVd, respectively (Table 4). Differences of canopy volume between treatments were observed 42 months after inoculation when both treatments with viroids differed from the controls but not from each other. At the $78^{\text {th }}$ month, the isolates differed from each other and from controls. One hundred and fifty months

Table 1- Scion trunk diameter of 'Marsh Seedless' grapefruit on trifoliate orange inoculated with viroids at different ages. [(CVd-II = Hop stunt viroid (HSVd, a non cachexia variant); CVd-III = Citrus III viroid) $]$.

\begin{tabular}{|c|c|c|c|c|c|}
\hline \multirow{2}{*}{ Treatments } & \multicolumn{5}{|c|}{ Months after inoculation } \\
\hline & 0 & 30 & 54 & 78 & 150 \\
\hline & $--u_{-1}$ & -1 & $-\mathrm{cm}-$ & & \\
\hline Absolute control & $1.81 \mathrm{a}^{1}$ & $7.65 \mathrm{a}$ & $10.35 \mathrm{a}$ & $13.45 \mathrm{a}$ & $17.40 \mathrm{a}$ \\
\hline Control & $1.66 \mathrm{a}$ & $7.67 \mathrm{a}$ & $10.20 \mathrm{a}$ & $13.55 \mathrm{a}$ & $17.60 \mathrm{a}$ \\
\hline CVd-II + CVd-III & $1.68 \mathrm{a}$ & $6.75 \mathrm{~b}$ & $8.35 \mathrm{~b}$ & $9.95 \mathrm{~b}$ & $12.41 \mathrm{~b}$ \\
\hline CEVd + CVd-II + CVd-III & $1.75 \mathrm{a}$ & $6.90 \mathrm{~b}$ & $8.05 \mathrm{~b}$ & $9.20 \mathrm{c}$ & $10.65 \mathrm{~b}$ \\
\hline
\end{tabular}

${ }^{1}$ Means followed by the same lower case letter in the column do not differ by the Tukey test (5\%).

Table 2 - Rootstock trunk diameter of 'Marsh Seedless' grapefruit on trifoliate orange inoculated with viroids at different ages. [(CVd-II = Hop stunt viroid (HSVd, a non cachexia variant); CVd-III = Citrus III viroid)].

\begin{tabular}{|c|c|c|c|c|c|}
\hline \multirow{2}{*}{ Treatments } & \multicolumn{5}{|c|}{ Months after inoculation } \\
\hline & 0 & 30 & 54 & 78 & 150 \\
\hline & $-\cdots-\cdots$ & $---\cdots-1$ & $--\mathrm{cm} \mathrm{--.}$ & & \\
\hline Absolute control & $2.73 \mathrm{a}^{1}$ & $10.66 \mathrm{a}$ & $14.15 \mathrm{a}$ & $19.15 \mathrm{a}$ & $23.85 \mathrm{a}$ \\
\hline Control & $2.51 \mathrm{a}$ & $10.18 \mathrm{ab}$ & $13.55 \mathrm{a}$ & $18.90 \mathrm{a}$ & $25.75 \mathrm{a}$ \\
\hline CVd-II + CVd-III & $2.43 \mathrm{a}$ & $9.40 \mathrm{bc}$ & $11.25 \mathrm{~b}$ & $13.75 \mathrm{~b}$ & $16.85 \mathrm{~b}$ \\
\hline CEVd + CVd-II + CVd-III & $2.75 \mathrm{a}$ & $9.01 \mathrm{c}$ & $9.85 \mathrm{c}$ & $11.75 \mathrm{c}$ & $13.30 \mathrm{c}$ \\
\hline
\end{tabular}

${ }^{1}$ Means followed by the same lower case letter in the column do not differ by the Tukey test (5\%).

Table 3 - Canopy diameter of 'Marsh Seedless' grapefruit on trifoliate orange inoculated with viroids at different ages. [(CVd-II = Hop stunt viroid (HSVd, a non cachexia variant); CVd-III = Citrus III viroid)].

\begin{tabular}{|c|c|c|c|c|c|}
\hline \multirow{2}{*}{ Treatments } & \multicolumn{5}{|c|}{ Months after inoculation } \\
\hline & 6 & 54 & 90 & 138 & 150 \\
\hline & $-\cdots-1$ & $-\ldots$ & $-m-\cdots$ & - n-n & $-\cdots--$ \\
\hline Absolute control & $1.50 \mathrm{a}^{1}$ & $3.56 \mathrm{a}$ & $4.51 \mathrm{a}$ & $4.87 \mathrm{a}$ & $5.17 \mathrm{a}$ \\
\hline Control & $1.47 \mathrm{a}$ & $3.46 \mathrm{a}$ & $4.55 \mathrm{a}$ & $5.08 \mathrm{a}$ & $5.53 \mathrm{a}$ \\
\hline CVd-II + CVd-III & $1.40 \mathrm{a}$ & $2.82 \mathrm{~b}$ & $3.17 \mathrm{~b}$ & $3.58 \mathrm{~b}$ & $3.89 \mathrm{~b}$ \\
\hline CEVd + CVd-II + CVd-III & $1.68 \mathrm{a}$ & $2.48 \mathrm{~b}$ & $2.59 \mathrm{c}$ & $2.70 \mathrm{c}$ & $2.88 \mathrm{c}$ \\
\hline
\end{tabular}

${ }^{1}$ Means followed by the same lower letter case in the column do not differ by the Tukey test (5\%). 
after inoculation, reductions of $84 \%$ and $62 \%$ related to absolute control were observed for the isolates with and without CEVd, respectively (Table 5).

Inoculated trees produced less fruit than the controls at the third harvest, which occurred 54 months after inoculation. Trees infected by isolate with CEVd consistently gave lower annual productivity compared to viroids isolate without CEVd, but differences were only observed at two dates, 66th and $150^{\text {th }}$ month of inoculation. The average productivity of fruits relative to absolute control was nearly $44 \%$ for isolate without CEVd and 33\% for the isolate with CEVd (Table 6).

Regarding crop efficiency, no differences were observed between the different treatments, except for treatment with CEVd 66 months after inoculation, which presented lower value than the others. In the average of eight evaluations, differences occurred between viroids isolates, the CEVd isolate showed lower value than the isolate without CEVd but they did not differ from the controls (Table 7).

Fruit quality was affected by treatments (Table 8). The CEVd treatment induced the lowest values of juice and weight but the highest value of ratio, while viroid treatment without CEVd was not different from the controls. Both viroids treatments gave higher TSS value than the controls. The effects of the isolate with CVd-II and CVd-III on trunk diameter, tree height and canopy volume have been observed earlier (between 30 and 42 months after inoculation) than it was re-

Table 4 - Tree height of 'Marsh Seedless' grapefruit on trifoliate orange inoculated with viroids at different ages. [(CVd-II = Hop stunt viroid (HSVd, a non cachexia variant); CVd-III = Citrus III viroid)].

\begin{tabular}{|c|c|c|c|c|c|}
\hline \multirow{2}{*}{ Treatments } & \multicolumn{5}{|c|}{ Months after inoculation } \\
\hline & 6 & 30 & 54 & 138 & 150 \\
\hline Absolute control & $1.66 \mathrm{a}^{1}$ & $2.35 \mathrm{a}$ & $3.08 \mathrm{a}$ & $3.94 \mathrm{a}$ & $4.30 \mathrm{a}$ \\
\hline Control & $1.53 \mathrm{a}$ & $2.47 \mathrm{a}$ & $3.04 \mathrm{a}$ & $4.36 \mathrm{a}$ & $4.75 \mathrm{a}$ \\
\hline CVd-II + CVd-III & $1.60 \mathrm{a}$ & $2.12 \mathrm{~b}$ & $2.33 \mathrm{~b}$ & $2.84 \mathrm{~b}$ & $3.03 \mathrm{~b}$ \\
\hline CEVd + CVd-II + CVd-III & $1.61 \mathrm{a}$ & $2.01 \mathrm{~b}$ & $2.08 \mathrm{c}$ & $2.24 \mathrm{c}$ & $2.26 \mathrm{c}$ \\
\hline
\end{tabular}

${ }^{1}$ Means followed by the same lower case letter in the column do not differ by the Tukey test (5\%).

Table 5 - Canopy volume of 'Marsh Seedless' grapefruit on trifoliate orange inoculated with viroids at different ages. [(CVd-II = Hop stunt viroid (HSVd, a non cachexia variant); CVd-III = Citrus III viroid)].

\begin{tabular}{lcrrrr}
\hline \multirow{2}{*}{ Treatments } & \multicolumn{4}{c}{ Months after inoculation } \\
\cline { 2 - 5 } & 6 & 42 & 78 & 138 & 150 \\
\hline Absolute control & $1.99 \mathrm{a}^{1}$ & $13.29 \mathrm{a}$ & $35.20 \mathrm{a}$ & $49.72 \mathrm{a}$ & $62.20 \mathrm{a}$ \\
Control & $1.74 \mathrm{a}$ & $12.75 \mathrm{a}$ & $37.79 \mathrm{a}$ & $59.02 \mathrm{~b}$ & $76.08 \mathrm{a}$ \\
CVd-II + CVd-III & $1.67 \mathrm{a}$ & $7.53 \mathrm{~b}$ & $15.72 \mathrm{~b}$ & $19.02 \mathrm{c}$ & $23.70 \mathrm{~b}$ \\
CEVd + CVd-II + CVd-III & $2.40 \mathrm{a}$ & $7.06 \mathrm{~b}$ & $8.75 \mathrm{c}$ & $8.87 \mathrm{~d}$ & $10.17 \mathrm{~b}$ \\
\hline
\end{tabular}

${ }^{1}$ Means followed by the same lower case letter in the column do not differ by the Tukey test (5\%).

Table 6 - Annual productivity of 'Marsh Seedless' grapefruit on trifoliate orange inoculated with viroids at different ages. [(CVd-II = Hop stunt viroid (HSVd, a non cachexia variant); CVd-III = Citrus III viroid)].

\begin{tabular}{|c|c|c|c|c|c|c|c|c|c|c|c|c|c|}
\hline \multirow{2}{*}{ Treatments } & \multicolumn{13}{|c|}{ Months after inoculation } \\
\hline & 30 & 42 & 54 & 66 & 78 & 90 & 102 & 114 & 126 & 138 & 150 & Mean & Relative \\
\hline & --- & $\cdots$ & -1 & 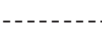 & 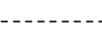 & $---\mathrm{k}$ & $e^{-1}$ & & & & & 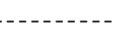 & $\%$ \\
\hline Absolute control & $26.6 \mathrm{a}^{1}$ & $63.2 \mathrm{a}$ & $128.3 \mathrm{a}$ & $156.3 \mathrm{a}$ & $114.4 \mathrm{a}$ & $175.6 \mathrm{a}$ & $201.0 \mathrm{a}$ & $154.5 \mathrm{a}$ & $133.0 \mathrm{a}$ & $43.9 \mathrm{~b}$ & $178.7 \mathrm{~b}$ & $134.1 \mathrm{a}$ & 100 \\
\hline Control & $27.2 \mathrm{a}$ & $65.4 \mathrm{a}$ & $117.0 \mathrm{a}$ & $132.3 \mathrm{a}$ & $121.9 \mathrm{a}$ & $181.0 \mathrm{a}$ & $201.8 \mathrm{a}$ & $163.3 \mathrm{a}$ & $151.5 \mathrm{a}$ & 23.8 & $270.6 \mathrm{a}$ & $150.5 \mathrm{a}$ & 116 \\
\hline CVd-II + CVd-III & $24.2 \mathrm{a}$ & $38.6 \mathrm{a}$ & $76.0 \mathrm{~b}$ & $86.1 \mathrm{~b}$ & $53.5 \mathrm{~b}$ & $72.5 \mathrm{~b}$ & $63.3 \mathrm{~b}$ & $51.1 \mathrm{~b}$ & $32.9 \mathrm{~b}$ & $65.9 \mathrm{c}$ & $89.7 \mathrm{c}$ & $59.4 \mathrm{~b}$ & 44 \\
\hline $\begin{array}{l}\text { CEVd + CVd-II + } \\
\text { CVd-III }\end{array}$ & $22.9 \mathrm{a}$ & $31.5 \mathrm{a}$ & $47.4 \mathrm{~b}$ & $30.7 \mathrm{c}$ & $18.3 \mathrm{~b}$ & $38.9 \mathrm{~b}$ & $29.0 \mathrm{~b}$ & $29.0 \mathrm{~b}$ & $19.8 \mathrm{~b}$ & $30.3 c$ & $34.9 c$ & $30.3 \mathrm{c}$ & 23 \\
\hline
\end{tabular}

${ }^{1}$ Means followed by the same lower case letter in the column do not differ by the Tukey test (5\%). 
Table 7 - Crop efficiency of 'Marsh Seedless' grapefruit on trifoliate orange inoculated with viroids at different ages. [(CVd-II = Hop stunt viroid (HSVd, a non cachexia variant); CVd-III = Citrus III viroid)].

\begin{tabular}{lccccccccc}
\hline \multirow{2}{*}{ Treatments } & \multicolumn{7}{c}{ Months after inoculation } \\
\cline { 2 - 9 } & 30 & 42 & 54 & 66 & 78 & 90 & 138 & 150 & Mean \\
\hline Absolute control & $2.92 \mathrm{a}^{1}$ & $4.80 \mathrm{a}$ & $6.31 \mathrm{a}$ & $7.77 \mathrm{a}$ & $3.30 \mathrm{a}$ & $4.55 \mathrm{a}$ & $2.89 \mathrm{a}$ & $2.74 \mathrm{a}$ & $4.41 \mathrm{ab}$ \\
Control & $2.85 \mathrm{a}$ & $5.20 \mathrm{a}$ & $6.12 \mathrm{a}$ & $6.56 \mathrm{a}$ & $3.22 \mathrm{a}$ & $4.64 \mathrm{a}$ & $3.79 \mathrm{a}$ & $3.61 \mathrm{a}$ & $4.50 \mathrm{ab}$ \\
CVd-II + CVd-III & $3.68 \mathrm{a}$ & $5.13 \mathrm{a}$ & $7.83 \mathrm{a}$ & $8.15 \mathrm{a}$ & $3.41 \mathrm{a}$ & $5.52 \mathrm{a}$ & $3.47 \mathrm{a}$ & $3.81 \mathrm{a}$ & $5.20 \mathrm{a}$ \\
CEVd + CVd-II + CVd-III & $3.30 \mathrm{a}$ & $4.43 \mathrm{a}$ & $7.28 \mathrm{a}$ & $3.52 \mathrm{~b}$ & $2.03 \mathrm{a}$ & $5.06 \mathrm{a}$ & $3.68 \mathrm{a}$ & $3.52 \mathrm{a}$ & $4.10 \mathrm{~b}$ \\
\hline
\end{tabular}

${ }^{1}$ Means followed by the same lower case letter in the column do not differ by the Tukey test (5\%).

Table 8 - Fruit quality characteristics of 'Marsh Seedless' grapefruit on trifoliate orange inoculated with viroids, 1996-2001. [(CVd-II = Hop stunt viroid (HSVd, a non cachexia variant); CVd-III = Citrus III viroid; TI = technological index; TSS $=$ total soluble solids)].

\begin{tabular}{|c|c|c|c|c|c|c|c|c|}
\hline Treatments & TI & Juice & Acidity & TSS & Ratio & Height & Diameter & Weight \\
\hline & $\mathrm{kg}^{\mathrm{TSS}}$ box $^{-1}$ & $-\ldots-1 \%$ & $-\ldots-\ldots$ & ${ }^{o}$ Brix & - & $-\ldots-\ldots$ & m ------- & g \\
\hline Absolute control & $1.82 \mathrm{ab}^{1}$ & $46.3 \mathrm{a}$ & $1.62 \mathrm{a}$ & $9.80 \mathrm{c}$ & $6.03 \mathrm{bc}$ & $8.26 \mathrm{a}$ & 8.82 a & $284 \mathrm{a}$ \\
\hline Control & $1.74 \mathrm{~b}$ & $45.3 \mathrm{a}$ & $1.67 \mathrm{a}$ & $9.49 \mathrm{c}$ & $5.67 \mathrm{c}$ & 8.16 a & $8.58 \mathrm{a}$ & $264 a b$ \\
\hline CVd-II + CVd-III & $1.96 \mathrm{a}$ & $44.2 \mathrm{a}$ & $1.67 \mathrm{a}$ & $10.99 \mathrm{~b}$ & $6.58 \mathrm{ab}$ & $7.96 \mathrm{a}$ & $8.41 \mathrm{a}$ & $249 \mathrm{ab}$ \\
\hline $\mathrm{CEVd}+\mathrm{CVd}-\mathrm{II}+\mathrm{CVd}-\mathrm{III}$ & $1.87 \mathrm{ab}$ & $40.7 \mathrm{~b}$ & $1.62 \mathrm{a}$ & $11.44 \mathrm{a}$ & $7.05 \mathrm{a}$ & $7.85 \mathrm{a}$ & $8.42 \mathrm{a}$ & $245 \mathrm{~b}$ \\
\hline
\end{tabular}

${ }^{1}$ Means followed by the same lower case letter in the column do not differ by the Tukey test (5\%).

ported in Australia (48 months after inoculation) for nonscaling isolates (most of them carrying CVd-II and CVd-III) onto trifoliate orange (Broadbent et al., 1994). Inoculation with the CEVd isolate resulted in extreme dwarfing (84\% reduction in canopy volume and only $2.26 \mathrm{~m}$ tall) confirming results from Australia (Broadbent et al., 1994; Forsyth et al., 1993). On the other hand, trees inoculated with the CVd-II and CVdIII isolate showed higher size reductions (62\%) than observed in Australia (50\%) for Valencia and Belamy Navel sweet orange (C. sinensis L. Osbeck) on trifoliate orange inoculated with four nonscaling isolates described by Gillings et al. (1991) (two carrying CVdIIa and CVd-IIIa, one carrying CVd-IIIa only and another one with CVd-IIb - a cachexia variant, plus CVdIIIa), which had similar behavior (Broadbent et al., 1994; Forsyth et al., 1993).

For Clementine mandarin (C. clementina Hort. ex Tan.) grafted on trifoliate orange 12 years after inoculation, rootstock circumference reduction was about $18 \%$ for trees carrying an isolate with CEVd and around 20,14, 15 and 19\% for those infected by isolates with CVd-IIIa, CVd-IIIc and CVd-IIId, respectively and nearly $13 \%$ for trees contaminated with one isolate with CVd-IIc. Scion circumference was nearly reduced by $24 \%$ for trees carrying CEVd and around 25 - 27\% for trees infected by isolates with CVd-IIIa, CVd-IIIb, CVd-IIIc and CVd-IIId separately (Verniere et al., 2004). Trees of Clementine mandarin on trifoli- ate orange infected with CEVd + CVd-II + CVd-III showed higher reduction in rootstock and scion circumference, 29 and 44\%, respectively, than those infected with CVd-II + CVd-III, which showed 14 and $30 \%$ of reduction in rootstock and scion circumference, respectively, 144 months after inoculation (Verniere et al., 2006).

Reduction in productivity was nearly $56 \%$ for trees with CVd-II and CVd-III isolate and $77 \%$ for those with CEVd, CVd-II and CVd-III isolate and was proportional to reduction in canopy volume as reported previously (Broadbent et al., 1994). Verniere et al. (2004) reported that losses on ten harvest cumulative yield of Clementine mandarin on trifoliate orange were about $48 \%$ for trees carrying two isolates with CEVd and around 38, 39 and $48 \%$ for those infected by isolates with CVd-IIIa, CVd-IIIc and CVd-IIId, respectively and nearly $34 \%$ for trees contaminated with CVd-IIc. Trees of Clementine on trifoliate orange infected with CEVd + CVd-II + CVd-III showed higher reduction in the ten season cumulative yield (53\%) than those infected with CVd-II + CVd-III (31\%) (Verniere et al, 2006).

Results on crop efficiency were in disagreement with results by Vuuren \& Graça (1997a) for trees of Delta Valencia sweet orange (C.sinensis) on Rubidoux trifoliate orange inoculated with two isolates, one with CEVd and another with CVd-III, by Vuuren \& Graça (1997b) for Delta Valencia sweet orange 
(C.sinensis) trees on several rootstocks, including two trifoliate orange selections (Rubidoux and Dwarf) inoculated with a CEVd + CVd-III isolate and a CVd-III isolate, by Semancik et al. (1997) who reported better crop efficiency for Valencia Campbell sweet orange (C.sinensis) trees on Rubidoux trifoliate orange inoculated with three isolates carrying a single viroid each: CVd-Ia, CVd-IIa and CVd-IIIb and Pompeu Junior et al. (1976) who found greater crop efficiency for trees of Hamlin sweet orange (C.sinensis) grafted on Rangpur lime (C.limonia Osbeck) inoculated separately with both a mild strain of exocortis as well as a severe one. On the other hand, Forsyth et al. (1993) and Broadbent et al. (1994) reported similar crop efficiency in their reviews about several trials conducted in Australia, as showed in the current work.

Research from Florida (Cohen, 1968, 1974) showed an effect of viroid inoculation on TSS of grapefruit. In both treatments with viroids, TSS values were higher than absolute control but there was not a commercial benefit thus the TI was the same for the absolute control and for both isolates.

The theoretical optimal planting density was 473 and 771 trees per hectare for trees inoculated with the CVd-II and CVd-III isolate and with the CEVd isolate, respectively. Therefore the theoretical potential yields were nearly 28 and $23 \mathrm{t} \mathrm{ha}^{-1}$, respectively, which are smaller than that obtained in uninoculated trees $\left(68 \mathrm{t} \mathrm{ha}^{-1}\right)$ at the density of 476 trees per hectare of the experiment.

Trees inoculated with viroids showed crop efficiency and fruit quality similar to healthy ones but the strong effect on tree size (84\% and $62 \%$ less canopy volume for isolate with and without CEVd, respectively) results in low productivity. The interaction of viroids related by Ito et al. (2002), Verniere et al. (2004. 2006) with antagonist or synergistic effects could contribute to the understanding of the extreme dwarfing observed, considering that there was an additive effect between CEVd and CVd-III (Verniere, 2006). The lack of irrigation and high temperatures of the site may also help explain this, considering that most of the research on viroids done elsewhere has been carried out in irrigated groves and in some cases in a less hot climate

\section{CONCLUSIONS}

The use of such severe dwarfing isolates for high density plantings of grapefruit on trifoliate orange rootstock is not recommended under non irrigated and high temperature conditions in Brazil.

\section{ACKNOWLEDGMENTS}

To CNPq for the scholarships of Eduardo Sanches Stuchi; to the technicians Luiz Gustavo Parolin and Dimas Alves de Toledo for their helpful assistance with fieldwork.

\section{REFERENCES}

ASHKENAZI, S.; OREN, Y. The use of citrus exocortis virus (CEV) for tree size control in Israel: practical aspects. . In: INTERNATIONAL CITRUS CONGRESS, 6., Tel Aviv, 1988. Proceedings. Rehovot: International Society of Citriculture, 1989. p.917-920.

BARBOSA, C.J.; PINA, J.A.; PÉREZ-PANADÉS; BERNARD, L.; SERRA, P.; NAVARRO, L.; DURAN-VILA, N. Mechanical transmission of citrus viroids. Plant Disease, v.89, p.749754, 2005.

BAR-JOSEPH, M. Citrus viroids and citrus dwarfing in Israel. Acta Horticulturae, n.349, p.271-275, 1993.

BROADBENT, P.; FORSYTH, J.B.; HUTTON, R.J; BEVINGTON, K.B. Guidelines for the commercial use of graft-transmissible dwarfing in Australia - potential benefits and risks. In: INTERNATIONAL CITRUS CONGRESS, 7., Acireale, 1992. Proceedings. Acireale: International Society of Citriculture, 1994. p.697-701.

COHEN, M. Exocortis virus as possible factor in producing dwarf citrus trees. Proceedings of the Florida State Horticultural Society, v.81, p.115-119, 1968.

COHEN, M. Effect of exocortis inoculation on performance of Marsh grapefruit tree on various rootstocks. In: CONFERENCE OF THE INTERNATIONAL ORGANIZATION OF CITRUS VIROLOGISTS, 6., Mbabane, 1974. Proceedings. Richmond: International Organization of Citrus Virologists, 1974. p.117121.

DE NEGRI, J.D.; BLASCO, E.E.A. Planejamento e implantação de um pomar cítrico. In: RODRIGUEZ, O.; VIEGAS, F.; POMPEU JUNIOR., J.; AMARO, A.A. (Ed.) Citricultura brasileira. Campinas: Fundação Cargill, 1991. v.1, p.318-332.

FORSYTH, J.B.; BARKLEY, P.; HUTTON, R.J.; BEVINGTON, K.B. Citrus high density management: dwarfing and guidelines for commercial use. Orange: NSW Agriculture \& Fisheries, Division of Plant Industries, 1993. 6p. (Agnote DPI/ 76).

GILLINGS, M.R.; BROADBENT, P.; GOLLNOW, B.I. Viroids in Australian citrus: relationship to exocortis, cachexia and citrus dwarfing. Australian Journal of Plant Physiology. East Melbourne, v.18, p.559-570, 1991.

GOLOMB, A. High density plantings of intensive citrus groves: a challenge and realization. In: INTERNATIONAL CITRUS CONGRESS, 6., Tel Aviv, 1988. Proceedings. Rehovot: International Society of Citriculture, 1989. p.921-930.

HADAS, R.; BAR-JOSEPH, M.; SEMANCIK, J.S. Segregation of a viroid complex from a graft-transmissible dwarfing agent source for grapefruit trees. Annals of Applied Biology, v.115, p.515520, 1989.

ITO, T.; IEKI, H.; OZAKI, K; IWANAMI, T.; NAKAHARA, K.; HATAYA, T.; ITO, T; ISAKA, M.; KANO, T. Multiple citrus viroids in citrus from Japan and their ability to produce exocortislike symptoms in citron. Phytopathology, v.92, p.542-547, 2002.

PÉREZ, R.; RODRÍGUEZ, R.; GONZÁLEZ, A.; DEL VALLE, N.; DURÁN-VILA, N. Dwarf citrus trees for high-density plantings. In: INTERNATIONAL CITRUS CONGRESS, 7., Acireale, 1992. Proceedings. Acireale: International Society of Citriculture, 1994. p.712-713. 
POLIZZI, G.; AZZARO, A.; CATARA, A. Effects of citrus viroids on different rootstocks. In: INTERNATIONAL CITRUS CONGRESS, 7., Acireale, 1992. Proceedings. Acireale: International Society of Citriculture, 1994. p.797-799.

POMPEU JUNIOR., J.; RODRIGUEZ, O.; TEÓFILO SOBRINHO, J.; NEVES, J.P.; SALIBE, A.A. Behavior of nucellar and old clones of Hamlin sweet orange on rangpur lime rootstock. In: CONFERENCE OF THE INTERNATIONAL ORGANIZATION OF CITRUS VIROLOGISTS, 7., Riverside, 1976. Proceedings. Riverside: International Organization of Citrus Virologists, 1976. p.96-97.

ROISTACHER, C.N. Dwarfing of citrus by use of citrus viroids pros and cons. In: INTERNATIONAL CITRUS CONGRESS, 7., Acireale, 1992. Proceedings. Acireale: International Society of Citriculture, 1994. p.791-796.

SEMANCIK, J.S.; ROISTACHER, C.N. The citrus viroid complex I. Citrograph, v.76, p.17-25, 1991a.

SEMANCIK, J.S.; ROISTACHER, C.N. The citrus viroid complex II. Citrograph, v. 76, p.9-11, 1991b.

SEMANCIK, J.S.; RAKOWSKI, A.G.; BASH, J.A.; GUMPF, D.J. Application of viroids selected for dwarfing citrus. In: INTERNATIONAL CITRUS CONGRESS, 8., Sun City, 1996. Proceedings. Nelspruit: International Society of Citriculture, 1997. p.701-704.

SEMANCIK, J.S.; BASH, J.A.; GUMPF, D.J. Induced dwarfing of citrus by transmissible small nuclear RNA (TsnRNA) In: CONFERENCE OF THE INTERNATIONAL ORGANIZATION OF CITRUS VIROLOGISTS, 15., Riverside, 2002. Proceedings. Riverside: International Organization of Citrus Virologists, 2002. p.390-391.

STUCHI, E.S.; DONADIO, L.C.; SEMPIONATO, O.R.; SILVA, J.A.A. Caracterização de cinco isolados de exocorte e efeitos de sua inoculação no desenvolvimento vegetativo e produção inicial de pomeleiro 'Marsh Seedless’ (Citrus paradisi Macf.). Revista Brasileira de Fruticultura, v.20, p.167-174, 1998.
STUCHI, E.S.; DONADIO, L.C.; SEMPIONATO, O.R. Segregação natural de viróides dos citros detectada pela indexação biológica e bioquímica e confirmada pelos sintomas de plantas de campo.

Revista Brasileira de Fruticultura, v.23, p.428-431, 2001.

TARGON, M.L.P.N.; MACHADO, M.A.; CARVALHO, S.A.; MULLER, G.W.; STUCHI. E.S. Diagnóstico molecular de viróides em citros. Laranja, v.22, p.243-257, 2001.

TUCKER, D.P.H.; WHEATON, T.A.; MURARO, R.P. Citrus tree spacing and pruning. Lake Alfred: University of Florida, Institute of Food and Agricultural Sciences, 1991. 15p. (SP 74).

VUUREN, S.P.; GRAÇA, J.V. Response of Valencia trees on different rootstocks to two citrus viroids isolates. In: INTERNATIONAL CITRUS CONGRESS, 8., Sun City, 1996. Proceedings. Nelspruit: International Society of Citriculture, 1997a. p.705-710.

VUUREN, S.P.; GRAÇA, J.V. Application of transmissible agents from dwarfed field trees to control tree size of sweet orange. . In: INTERNATIONAL CITRUS CONGRESS, 8., Sun City, 1996. Proceedings. Nelspruit: International Society of Citriculture, 1997b. p.711-717.

VERNIERE, C.; PERRIER, X.; DUBOIS, C.; DUBOIS, A.; BOTELLA, L.; CHABRIER, C.; BOVÉ, J.M.; DURAN-VILA, $\mathrm{N}$. Interactions between citrus viroids affect symptom expression and field performance of Clementine trees grafted on trifoliate orange. Phytopathology, v.96, p.356-368, 2006.

VERNIERE, C.; PERRIER, X.; DUBOIS, C.; DUBOIS, A.; BOTELLA, A.; CHABRIER, C.; BOVÉ, J.M.; DURAN-VILA, N. Citrus viroids: symptom expression and effect on vegetative growth and yield of Clementine grafted on trifoliate orange. Plant Disease, v.88, p.1189-1197, 2004.

VOGEL, R.; BLONDEL, L.; BOVÉ, J.M. Influence de l'exocortis sur le dévelopment et la production du clémentinier greffé sur Poncirus trifoliata. Fruits, v.29, p.367-373. 1974.

Received March 27, 2006

Accepted September 04, 2007 